\title{
TAFSIR AYAT-AYAT KE-PANCASILA-AN
}

\author{
${ }^{1}$ Agus Tohawi \\ agustohawi17@gmail.com \\ Dosen Institut Agama Islam Pangeran Diponegoro Nganjuk

\section{${ }^{2}$ Suwandi} \\ suwandi.ardiansyah@gmail.com \\ Pascasarjana Institut Agama Islam Pangeran Diponegoro Nganjuk
}

Abstrak: Indonesia merdeka berkat perjuangan para pahlawan yang memiliki latar belakang agama berbeda-beda. Jika salah satu dari beragam agama tersebut mengedapankan egonya, maka tidak akan terjadi kesepakatan. Berkat kesepakatan itulah Indonesia memiliki dasar Pancasila yang dapat mempertemukan seluruh elemen untuk bersama-sama membangun bangsa ini menjadi lebih baik. Secara tersurat maupun tersirat, sesungguhnya Pancasila memiliki dasar dari al-Qur'an. Artikel ini akan membahas penafsiran ayat-ayat ke-Pancasila-an dari sudut pandangn tafsir tematik. Kesimpulan artikel ini adalah: Sila pertama memiliki dasar dari surah al-Ikhlāṣ ayat pertama dan al-Baqarah ayat 163 tentang ke-Esaan Tuhan; Sila kedua memiliki dasar dari surah Al-Shūra ayat 15 (supaya berbuat adil antar sesama) dan Al-Nahl ayat 90 (adil dan ibsan); Sila ketiga memiliki dasar dari surah Āli 'Imrān ayat 103 (supaya bersatu padu dan jangan bercerai-berai) dan Al-Ḥjurāt ayat 10 (antar sesama adalah saudara) dan 13 (supaya saling memahami satu sama lain); Sila keempat memiliki dasar dari surah Al-Baqarah ayat 269 (bikmat), Āli 'Imrān ayat 159 (musyawarah), Ṭāhā ayat 30-32 (asas perwakilan), Al-Nisā' ayat 58 (asas perwakilan); Sila kelima memiliki dasar dari surah Al-Ma'idah ayat 8 (asas keadilan) dan al-Tawbah ayat 60 (asas keadilan yang memihak kepada rakyat kecil).

Kata kunci: Tafsir tematik, Pancasila.

Spiritualis, vol. 6, no. 2, September 2020

ISSN: $2442-5907 \mid 210$ 
Spiritualis: vol. 6, no. 2, September, $2020 \mid 211$

\section{Pendahuluan}

Penentuan dasar negara Indonesia berupa Pancasila ini telah melalui tahapan sejarah yang sangat panjang. Umat Islam pada masa itu juga telah mengupayakan ego-teologisnya untuk masuk ke dalam ranah dasar negara. Namun sejarah membuktikan bahwa hal itu tidak bisa dilakukan karena unsur warga negara yang beragam. Adanya kalimat "Dengan menjalankan syariat Islam bagi para pemeluk-pemeluknya" dalam sila pertama merupakan salah satu contoh yang tidak dapat diterima oleh kalangan non Muslim. Jika hal itu dipaksakan, maka Indonesia wilayah timur akan lepas dari Indonesia. Dengan pertimbangan bersama, akhirnya kalimat tersebut di delete. Selain itu, para pahlawan yang memperjuangkan bangsa ini juga bukan dari kalangan muslim saja. Dengan demikian, seluruh elemen harus dirangkul demi untuk mewujudkan persatuan dan kesatuan bangsa.

Pada akhirnya, Pancasila dirumuskan dan disahkan menjadi lima sila, yaitu: 1. Ketuhanan Yang Maha Esa; 2. Kemanusiaan yang adil dan beradab; 3. Persatuan Indonesia; 4. Kerakyatan yang dipimpin oleh hikmat kebijaksanaan dalam permusyawaratan perwakilan; 5. Keadilan sosial bagi seluruh rakyat Indonesia. Kelima sila ini kemudian memiliki simbol masing-masing. Sila pertama memiliki simbol satu bintang. Sila kedua memiliki simbol rantai. Sila ketiga memiliki simbol pohon beringin. Sila keempat memiliki simbol kepala banteng dan; Sila kelima memiliki simbol padi dan kapas. 
Spiritualis: vol. 6, no. 2, September, $2020 \mid 212$

\section{Metode Penelitian (Tafsir Tematik)}

Tafsir tematik dapat dibagi menjadi dua, yaitu tematik dari dalam al-Qur'an dan dari luar al-Qur'an. Tematik yang diambil dari dalam al-Qur'an yaitu menyangkut kata-kata yang tersurat di dalam al-Qur'an (sarị). Sedangkan tafsir tematik dari luar al-Qur'an, yaitu tema atau kata-kata yang tidak tertulis secara langsung di dalam alQur'an namun substansinya disinggung oleh al-Qur'an. ${ }^{1}$

Sedangkan penelitian ini menggunakan dua pendekatan tersebut sebab, Pancasila memiliki lima sila yang terstrukur dan rapi kemudian dicari ayat-ayat yang berkaitan tentang kelima sila tersebut. Dari lima sila tersebut ada yang ditemukan ayat secara tersurat dan ada pula ayat yang tersirat. Penyusunan runtutan penafsiran di dalam artikel ini menggunakan barometr urutan dari Pancasila, mulai dari sila pertama hingga terakhir (kelima). Penyusunan ini dilakukan atas pertimbangan kemudahan di dalam mencari legitimasi ayat-ayat yang membahas tentang Pancasila.

\section{Pembahasan}

1. Ketuhanan Yang Maha Esa

Sila pertama adalah Ketuhanan Yang Maha Esa. Sila ini memiliki dasar di dalam al-Qur'an, surah Al-Ikhlāṣ [112] ayat pertama. Allah berfirman:

\footnotetext{
${ }^{1}$ Abdur Rohman, Tafseer Verses of Diversity, dalam Proceeding "Medorasi Islam Aswaja untuk Perdamaian Dunia" IAIFA Pare Kediri, vol. 1, 2019, 158.
} 
Spiritualis: vol. 6, no. 2, September, $2020 \mid 213$

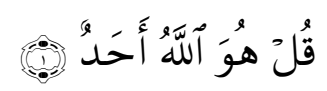

Katakanlah (Wabai Muhammad) "Dia-lah Allah, yang Maha Esa.

Konteks ayat ini membicarakan tentang perdebatan Nabi dengan orang-orang musyrik yang ada di sekitarnya. Berdasarkan riwayat dari Aḥmad, Tirmidhi, dan Ibnu Jarir dari Ubay bin Ka'ab menjelaskan bahwa orang-orang musyrik bertanya kepada Rasulullah saw. tentang nasab Tuhannya? Kemudian Allah menurunkan qul huwa Allăhu aḥad (Katakan, Tuhan itu Esa). Orang-orang musyrik ingin memperdebatkan tentang ketuhanan di dalam Islam. Ayat ini dengan tegas menyatakan bahwa, ke-Esaan Tuhan itu menegasikan unsur-unsur yang dipertanyakan oleh orang-orang musyrik tersebut. Pertanyaan mengenai nasab Tuhan, secara eksplisit dinyatakan tertolak karena jawaban Tuhan itu Esa, berarti meniadakan nasab. Yang memiliki nasab pasti mati, yang mati pasti akan meninggalkan warisan. Sedangkan Allah tidak mati dan tidak dapat diwarisi. ${ }^{2}$ Sedangkan riwayat dari Ibnu 'Abbās menyatakan bahwa ada salah seorang Quraish yang menanyakan kepada Nabi perihal Allah. "Dari apakah ia, emas atau perak? Kemudian Allah menurunkan surah al-Ikhlāṣ ini."

Dasar kedua mengenai ke-Esaan Tuhan terdapat di dalam surah al-Baqarah [2] ayat 163:

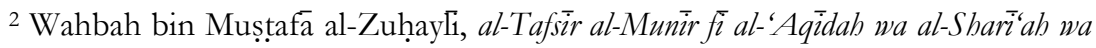
al-Manbaj (Damaskus: Dār al-Fikr al-Ma'ạșir, 1418), vol. xv, 463.

${ }_{3}^{3}$ Abū T⿳ăhir bin Ya'qūb al-Fayrüzi Abadi, Tanwīir al-Miqbās min Tafsìr Ibni 'Abbās (Kairo: Shirkah al-Quds, 2007), 604.
} 


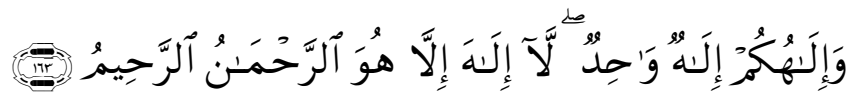

Dan Tuhanmu adalab Tuban yang Maha Esa; tidak ada Tuhan melainkan Dia yang Maha Pemurah lagi Maha Penyayang.

Abū al-Layth al-Samarqandi di dalam kitabnya menjelaskan bahwa Tuhan kamu sekalian adalah Tuhan Yang Maha Esa. Ia juga menyatakan bahwa ayat ini turun berkenaan dengan asumsi orangorang Majusi yang memiliki sebutan al-Manūwiyah, yang dipimpin oleh Māni, ia menyatakan bahwa segala sesuatu di dunia ini diciptakan berpasang-pasangan. Siang dengan malam, gelap dengan terang, panas dengan dingin, kebaikan dengan keburukan, bahagia dengan sedih, dan sesuatu yang patut atas sesuatu itu, tidak patut disandarkan kepada yang lain, maka barangsiapa menciptakan kebaikan dan cahaya, maka ia tidak patut menciptakan keburukan dan kegelapan.

Kemudian Allah menurunkan ayat ini sebagai bantahan atas asumsi mereka, bahwa Allah adalah Tuhan Yang Esa, yang mana semua hal disandarkan kepada-Nya. ${ }^{4}$ Khitab wa ilāhukum ilāhun wạhid ini sebenarnya ditujukan kepada seluruh manusia, bukan hanya orang Islam dan Ahli Kitab saja. Pada dasarnya, secara naluriah-alamiah, seluruh manusia sebenarnya hanya mengakui satu Tuhan. Oleh karena itu, sila pertama "Ketunanan Yang Maha Esa" disetuji oleh seluruh pemeluk agama yang ada di Indonesia.

\footnotetext{
${ }^{4}$ Abū al-Layth Naṣr bin Muhammad bin Ibrāhim al-Samarqandi, Baḥr al-Ulüm (al-maktabah al-Shmāmilah), QS. Al-Ikhlāṣ [112], 1.
} 
Spiritualis: vol. 6, no. 2, September, 2020 |215

2. Kemanusiaan Yang Adil dan Beradab

Sila kedua adalah "Kemanusiaan yang adil dan beradab". Asas keadilan di dalam sila ini dapat ditemukan di dalam surah AlShūra [42] ayat 15:

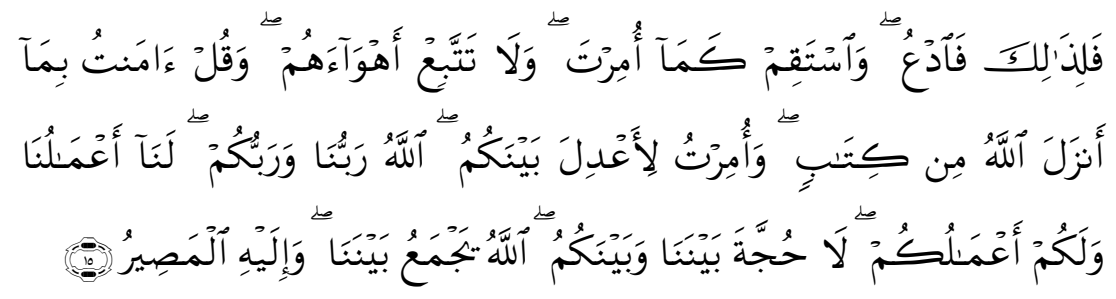

Maka karena itu serulab (mereka kepada agama ini) dan tetaplab sebagaimana diperintabkan kepadamu dan janganlah mengikuti bawa nafsu mereka dan katakanlab: "Aku beriman kepada semua kitab yang diturunkan Allab dan aku diperintabkan supaya berlaku adil diantara kamu. Allah-lah Tuban kami dan Tuhan kamu. Bagi kami amal-amal kami dan bagi kamu amal-amal kamu. Tidak ada pertengkaran antara kami dan kamu, Allah mengumpulkan antara kita dan kepada-Nyalah kembali".

Mahal al-shabid ayat ini yang membicarakan persoalan keadilan terdapat pada redaksi wa umirtu li a'dala baynakum (dan aku (Muhammad) diperintahkan supaya adil kepadamu). Maksud keadilan di dalam ayat ini menurut mufasir dari Cordoba Spanyol, al-Qurțubi adalah "keadilan dalam segala hal, dan ada pula yang menyatakan keadilan hukum". Seorang mufasir ahli hukum tata negara dari Irak, al-Māwardi menyatakan bahwa keadilan yang

5 Abū 'Abd Allāh Muḥammad bin Aḥmad bin Abū Bakr bin Farh al-Anșāāi

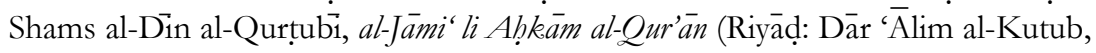
2003), juz xvi, 13. 
Spiritualis: vol. 6, no. 2, September, 2020 |216

dimaksud di dalam ayat ini ada dua makna, yaitu keadilan dari segi hukum dan keadilan dari segi dakwah. ${ }^{6}$ Kata 'adil' di dalam bahasa Indonesia sebenarnya adalah bahasa serapan dari bahasa Arab 'adl. Kata 'adil' (dalam bahasa Indonesia) ketika dikembalikan ke dalam al-Qur'an, setidaknya ada dua makna, yaitu al-'adlu dan al-qist. Kedua kata ini jika diterjemahkan ke dalam bahasa Indonesia sama-sama bermakna adil. Namun perbedaan dari dua diksi ini dapat ditemukan di dalam surah al-Nisā' [4]:4 yang menjelaskan tentang poligami. Di dalamnya ada kata an là tuqsitu $\bar{f} \bar{i}$ al-yatama $\bar{a}$ dan an lata 'dilú fawāḥidah. Makna dari perbedaan redaksi tersebut adalah: qistu digunakan oleh al-Qur'an untuk menyatakan keadilan dalam ranah kuantitatif. Sedangkan al-'adl lebih menekankan keadilan psikologis dan sosial. ${ }^{7}$

Asas keadilan yang kedua dijelaskan di dalam surah AlNahl [16] ayat 90:

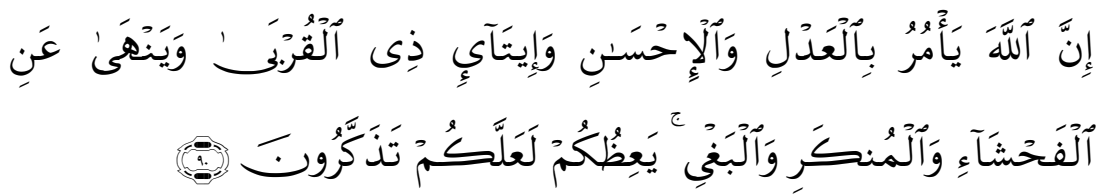

Sesungguhnya Allah menyuruh (kamu) berlaku adil dan berbuat kebajikan, memberi kepada kaum kerabat, dan Allab melarang perbuatan keji, kemungkaran dan permusuban. Dia memberi pengajaran kepadamu agar kamu dapat mengambil pelajaran.

6 Abū Hasan 'Ali bin Muḥammad bin Habib al-Māwardi, al-Nukat wa al-'Uyūn (Beirut: Dār al-Kutub al-'Ilmiyyah, 2012), vol. V, 199.

7 Abdur Rohman "Poligami" dalam jurnal Agenda, IAIN Batusangkar, vol. 2 nomor 1 Juli-Desember, 2019, 3-4. 
Al-Samarqandi menjelaskan bahwa makna al-'adl di dalam ayat ini adalah mentauhidkan Allah dan ihssān adalah berbuat baik kepada sesama. Selain itu, lanjutan ayat ini juga memerintahkan untuk menjaga tali silaturahim, menjauhkan diri dari segala perkara yang dapat menimbulkan perbuatan zina, kemungkaran (perkara yang tidak disyariatkan dalam Islam dan terancam siksa neraka) serta larangan berbuat permusuhan atau sombong. ${ }^{8}$ Sedangkan Ibnu Kathir lebih luas lagi di dalam memaknai kata 'adl tersebut. Ia menyatakan bahwa 'adl adalah al-qist wa al-mawärinah" (adil dan setara).

Sementara Zamakhshari memaknai kata tersebut dengan menunaikan segala kewajiban kepada Allah. ${ }^{10}$ Dalam arti, segala sesuatu yang diwajibkan oleh Allah adalah untuk kebaikan manusia itu sendiri. Jika seorang hamba menunaikan kewajiban memberikan zakat, maka zakat itu akan berdampak kepada stabilitas sosial dan dapat menurunkan angka ketimpangan. Jika seorang hamba menunaikan kewajibannya mencari nafkah untuk keluarga, maka dia sudah melaksanakan atau menggugurkan kewajiban agama dan meringankan beban keluarganya.

Jika mencermati makna keadilan yang telah dijelaskan oleh para mufasir di atas, maka dapat ditarik kesimpulan bahwa keadilan

\footnotetext{
${ }^{8}$ Al-Samarqandi, QS. Al-Naḥl [16]:90.

${ }^{9}$ Abū al-Fidā' Ismāīil bin 'Umar bin Kathir, Tafsì al-Qur'an al-Ažì (Kairo: Dār TTaybah, 1999), vol. iv, 595.

${ }^{10}$ Abū al-Qāsim Mahmūd bin 'Umar al-Zamakhshari, al-Kashshāf 'an Haqāiq alGhawāmid al-Tanzìl wa 'Uyūn al-Aqāwil fī Wujūh al-Ta'wīl (Beirut: Dār al-Kutub al'Arabi, 1407), vol. ii, 628.
} 
Spiritualis: vol. 6, no. 2, September, $2020 \mid 218$

yang dimaksud ada yang bersifat spesifik dan ada pula yang bersifat umum. Keadilan yang spesifik adalah keadilan dalam ranah hukum. Hukum seharusnya tidak memandang bulu, dan seringkali disimbolkan dengan orang yang matanya tertutup dengan membawa timbangan. Itu artinya, pihak penegak hukum harus menerapkan asas keadilan bagi siapapun tanpa melihat siapa yang sedang melanggar hukum tersebut. Keadilan kedua dalam ranah vertikal dan horizontal. Dalam ranah vertikal, seseorang yang melakukan kewajiban agama juga dianggap adil. Dalam konteks kenegaraan, orang yang melakukan ibadah shalat adalah adil dari segi akidah, sebab ia sudah memposisikan diri sebagaimana mestinya, yaitu sebagai seorang hamba yang taat beragama.

Begitu juga dalam agama lain yang melaksanakan ajaran agama dianggap sudah adil dari sudut pandang agama masingmasing. Sedangkan keadilan dalam ranah horizontal lebih familiar disebut dengan habl min al-nās (hubungan antar sesama manusia). Di dalam Islam sangat banyak ajaran yang memerintahkan kepada umatnya untuk berbuat baik terhadap sesama. Salah satu bentuk kewajiban untuk mempedulikan sesama adalah dengan cara menunaikan zakat. Zakat adalah kewajiban bagi umat Islam yang kaya untuk mendermakan sebagian hartanya kepada golongan strata sosial yang paling bawah. Jika saja orang-orang kaya di negara ini memiliki perhatian besar terhadap lingkungan masingmasing, maka proses pengentasan kemiskinan akan menjadi lebih efektif. Jika dicermati lebih mendalam, maka dapat ditarik kesimpulan bahwa keadilan di sini dapat dimaknai keadilan 
ekonomi, keadilan hukum dan keadilan diri seorang hamba dalam menempatkan posisinya di hadapan Tuhan. Itulah dasar penafsiran al-Qur'an yang dapat mempertemukan dengan sila "Kemanusiaan yang adil dan beradab”.

3. Persatuan Indonesia

Indonesia memiliki beragam suku, ras, agama, dan budaya. Perbedaan ini jika tidak dipupuk dengan baik, akan berpotensi menjadi konflik yang dapat memecah-belah bangsa. Oleh karena itu, di dalam sila yang ketiga ini dijelaskan tentang "Persatuan Indonesia". Asas persatuan juga diajarkan al-Qur'an di dalam surah Âli 'Imrān [3] ayat 103:

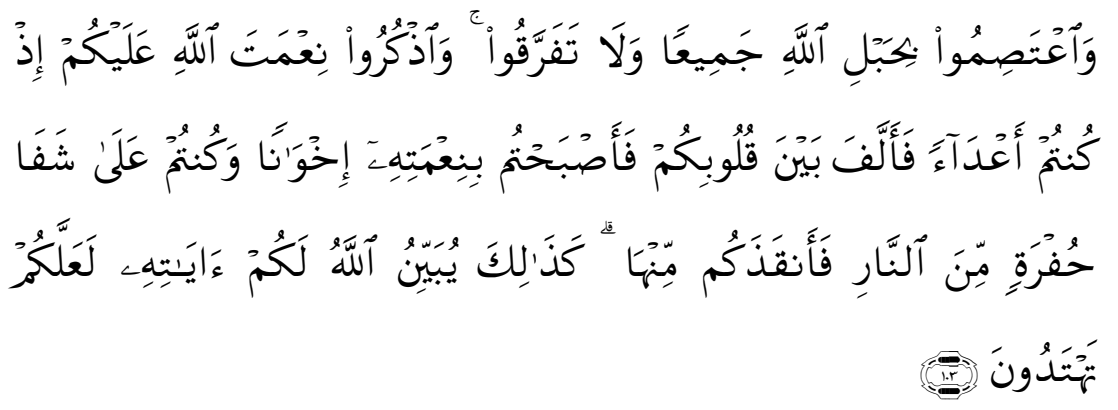

Dan berpeganglah kamu semuanya kepada tali (agama) Allah, dan janganlah kamu bercerai berai, dan ingatlah akan nikmat Allah kepadamu ketika kamu dabulu (masa Jabiliyah) bermusub-musuban, maka Allah mempersatukan hatimu, lalu menjadilab kamu karena nikmat Allah, orangorang yang bersaudara; dan kamu telah berada di tepi jurang neraka, lalu Allah menyelamatkan kamu dari padanya. Demikianlah Allah menerangkan ayat-ayat-Nya kepadamu, agar kamu mendapat petunjuk. 
Spiritualis: vol. 6, no. 2, September, $2020 \mid 220$

Konteks ayat ini membicarakan tentang dua suku, Auz dan Khazraj. Pada saat mereka telah masuk Islam, suatu hari mereka membicarakan masa lalunya, yang sering berperang dan bermusuhan, karena teringat kembali masa lalu yang buruk itulah, bincang-bincang mereka menjadi memanas dan hampir saja terjadi pertikaian. Atas peristiwa inilah ayat tersebut turun. ${ }^{11}$ Masingmasing dari keduanya diperintahkan oleh Allah supaya muḅasabah diri. Islam datang telah mendamaikan mereka dan mempersatukan mereka atas dasar iman dan persaudaraan. Padahal sebelumnya mereka dalam kekafiran dan permusuhan.

Al-Qur'an bukanlah kitab yang diturunkan kepada suku Aus dan Kahzraj saja. Oleh karena itu kedua nama tersebut tidak disebutkan oleh al-Qur'an, karena al-Qur'an untuk seluruh umat manusia. Termasuk untuk bangsa Indonesia yang memiliki beragam suku dan agama. Allah telah mempersatukan Aus dan Khazraj dalam satu iman juga dapat dikontekstualisasikan sebagai persatuan bangsa Indonesia. Atas dasar Indonesia, para penduduk yang beragam di dalamnya bisa bersatu padu. Oleh karena itu, Allah memerintahkan kepada penduduknya agar bersatu dan menjauhi perpecahan. Persatuan akan menambah kekuatan dan perpecahan akan menyebabkan kelemahan. Ibarat sebuah lidi, jika hanya satu, maka akan kesulitan membersihkan dedaunan. Akan tetapi jika lidi-lidi tersebut diikat dan disatukan, maka dedaunan yang berserakan itu akan mudah dibersihkan. Itulah analogi

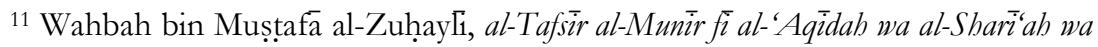
al-Manbaj (Beirut: Dār al-Fikr al-Ma'àṣir, 2016), vol. ii, 347.
} 
Spiritualis: vol. 6, no. 2, September, 2020 |221

persatuan. Semakin besar suatu bangsa, maka semakin besar pula kekuatannya. Semakin kecil suatu bangsa, maka semakin kecil pula kekuatannya.

Ayat kedua yang menjelaskan tentang asas persatuan adalah surah al-Hujurāt [49] ayat 10 dan 13:

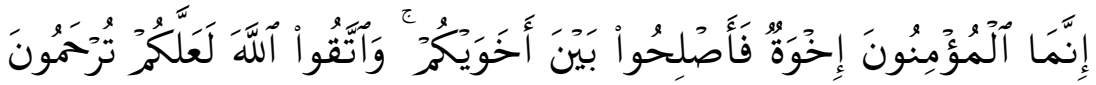

Orang-orang beriman itu sesunggubnya bersaudara. Oleb sebab itu damaikanlah (perbaikilah bubungan) antara kedua saudaramu itu dan takutlah terhadap Allah, supaya kamu mendapat rahmat.

Secara eksplisit ayat ini membicarakan tentang persaudaraan antar sesama umat Islam yang didasarkan persamaan se-iman, yaitu sama-sama iman kepada Allah. Di dalam ayat ini mereka digambarkan seperti halnya saudara. Pemahaman demikian karena redaksi ayat innamā al-mu'minūna ikhwatun adalah tashbih baligh yang membuang huruf tashbih-nya. Jika ditampakkan, maka redaksinya adalah innamā al-mu'minūna ka al-ikhwati.

Di dalam hadis juga disebutkan bahwa orang mukmin yang satu dengan mukmin lain bagaikan bangunan yang saling menguatkan. ${ }^{12}$ Ada pula perumpamaan lain yang mengibaratkan seperti halnya satu tubuh. Apabila yang satu sakit, maka bagian

12 Muhammad bin Ismā̄il bin Ibrāhim bin al-Mughirah al-Bukhārì, al-Jāmi‘ alȘahịh (Kairo: Dār al-Shu'ab, 1987), vol. viii, 14. 
tubuh yang lain juga ikut merasakan. ${ }^{13}$ Jadi, sesama muslim tidak boleh saling bermusuhan, tidak boleh bertengkar apalagi bercerai berai. Persatuan harus dikuatkan karena kekuatan negara ada pada persatuan. Jika umat Islam yang terbesar di negara ini berceraiberai, maka perdamaian dan kemakmuran akan semakin jauh.

Dalam konteks bernegara, telah lazim didengar persaudaraan atas dasar satu bangsa, satu bahasa, bahasa Indonesia. Ikrar Sumpah Pemuda merupakan wujud dari kecintaan warga negaranya kepada bangsa ini meskipun wujud dari kemerdekaan belum dirasakan pada saat itu. Oleh karenannya, jika seseorang tidak dapat bersatu atas nama agama, minimal dia bisa bersatu atas nama negara, Indonesia. Implementasi ini sangat kuat dirasakan oleh mereka yang sedang ke luar negeri, baik dalam misi belajar maupun menjadi TKI. Lebih jauh dari itu, seorang pakar tafsir nusantara menyatakan bahwa "Jika kita tidak dapat disatukan atas dasar iman, maka kita bisa disatukan atas dasar kemanusiaan”.

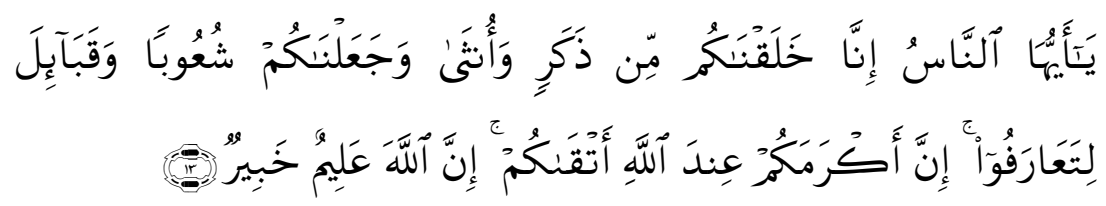

Hai manusia, sesunggubnya Kami menciptakan kamu dari seorang laki-laki dan seorang perempuan dan menjadikan kamu berbangsa - bangsa dan bersuku-suku supaya kamu saling kenal-mengenal. Sesunggubnya orang yang paling mulia diantara kamu disisi Allab ialab orang yang paling takwa. Sesunggubnya Allah Maba Mengetabui lagi Maha Mengenal.

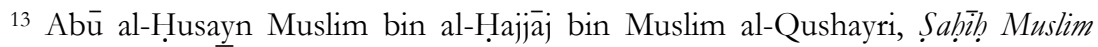
(Beirut: Dār al-Äfàq al-Jadidah, t. th), vol. viii, 20. 
Spiritualis: vol. 6, no. 2, September, $2020 \mid 223$

Meskipun al-Qur'an adalah kitab suci umat Islam, akan tetapi khitāb ayat ini ditujukan kepada umat manusia. Itu artinya, dalam konteks ini yang dieru bukan hanya umat Islam, tetapi seluruh umat manusia. Baik yang ada di Indonesia, Amerika, Inggris dan lain sebagainya. Baik orang yang beragama Kristen, Yahudi, Hindu, Budha atau yang lainnya. Semua masuk dalam khitab ini.

Di dalam ayat tersebut Allah menegaskan bahwa penciptaan manusia itu memang berbeda-beda. Perbedaan eksplisit yang dijelaskan oleh al-Qur'an adalah perbedaan antara laki-laki dan perempuan serta perbedaan bangsa dan suku. Allah menciptakan perbedaan tersebut supaya umat manusia saling mengerti dan memahami. Mengerti akan ke-khasan masing-masing orang dan memahami tentang budaya dan agama mereka. Secara tidak langsung, ayat ini juga menjadi dasar dari ilmu antropologi yang memotret manusia dan budayanya dari sisi ke-khasan mereka, bukan dari kacamata orang lain, dan orang lain harus mengerti dan memahami budaya setempat.

Penutupan ayat ini menegaskan bahwa manusia yang paling mulia di sisi Allah adalah yang paling takwa. Bukan mereka yang kaya, bukan mereka yang kuat, bukan kaum laki-laki, bukan orang yang berkulit putih dam bukan pula barometer yang lain, barometernya adalah sama, yaitu ketundukan dan ketaatan kepada perintah Allah. Jadi, di dalam hal ini semua memiliki kesempatan dan porsi yang sama dan potensi yang sama pula. 
Spiritualis: vol. 6, no. 2, September, $2020 \mid 224$

4. Kerakyatan yang Dipimpin oleh Hikmat, Kebijaksanaan dalam Permusyawaratan, Perwakilan

Asas pertama dalam sila keempat adalah "Kerakyatan yang dipimpin oleh hikmat". Ayat al-Qur'an yang menyinggung persoalan ini terdapat di dalam surah al-Baqarah [2] ayat 269 sebagai berikut:

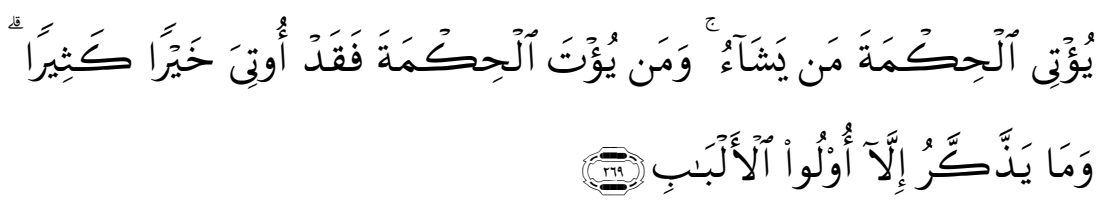

Allah menganugerabkan bikemah kepada siapa yang dikehendaki-Nya. dan barangsiapa yang dianugerahi hikmah, ia benar-benar telah dianugerahi karunia yang banyak. dan hanya orang-orang yang berakallah yang dapat mengambil pelajaran (dari firman Allab).

Konteks ayat ini membicarakan tentang Muhammad yang diberi hikmah oleh Allah berupa kenabian, kemampuan menafsirkan al-Qur'an, memiliki tutur kata yang halus dan fasih, memiliki pandangan yang sangat tajam dan berbagai kelebihan lainnya. Orang yang diberi hikmah oleh Allah berarti dia mendapatkan banyak kebaikan.

Dalam konteks kenegaraan, ayat di atas memang tidak saklek membicarakan persoalan yang sama dengan sila keempat tersebut. Akan tetapi, redaksi hikmat memang diambil dari bahasa Arab dan bahasa Arab merujuk kepada al-Qur'an. Oleh karena itu, pemaknaanya yang pertama harus dikembalikan ke sana.

Kata ḩikmah di dalam bahasa Arab saat diterjemahkan ke dalam bahasa Indonesia maknanya adalah bijaksana. Di dalam 
Asmā' al-Ḥsuna terdapat salah satu nama al-Hakim yang diterjemahkan dengan Maha Bijaksana. Jika ada seorang murid yang melanggar aturan sekolah yang seharusnya dihukum dengan hukuman yang berlaku, akan tetapi si guru tersebut mengganti dengan hukuman yang lain atas pertimbangan 'si murid sangat mudah putus asa'. Bisa jadi, jika guru tersebut mengambil tindakan tegas atas pelanggaran tersebut, maka murid tersebut putus sekolah. Oleh karena itu, kepekaan atas pelanggaran itu adalah si guru menghukum dengan bentuk lain supaya si murid tidak putus sekolah dan melanjutkan sekolahnya, sembari memperbaiki kesalahannya tadi. Itulah keputusan yang bijaksana. Jadi, tipikal seperti itulah pemimpin yang diharapkan dalam Pancasila. Dia memiliki kepekaan tingkat tinggi dan memiliki pengetahuan yang luas tentang rakyatnya sehingga bisa mengambil keputusan yang bijaksana.

Asas kedua dalam sila keempat mengenai "permusyawaratan" memiliki dasar dari surah ÂAi 'Imrān [3] ayat 159, Allah berfirman:

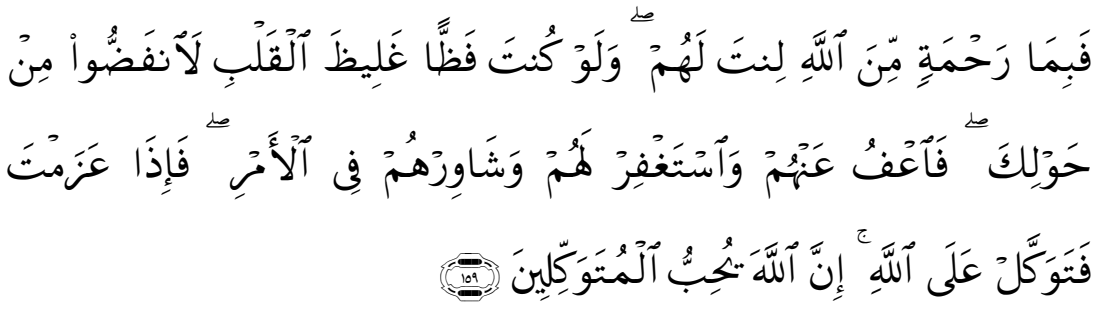

Maka disebabkan rabmat dari Allab-lah kamu berlaku lemah lembut terhadap mereka. Sekiranya kamu bersikap keras lagi berbati kasar, 
tentulah mereka menjaubkan diri dari sekelilingmu. Karena itu ma'afkanlah mereka, mohonkanlah ampun bagi mereka, dan bermusyawarablah dengan mereka dalam urusan itu. Kemudian apabila kamu telab membulatkan tekat, maka bertawakallah kepada Allah. Sesunggubnya Allab menyukai orang-orang yang bertawakal kepada-Nya.

Koteks ayat ini membicarakan tentang kebijkan Rasulullah kepada penduduk Madinah. Di dalamnya - selian umat Islam yang taat - juga ada orang-orang munafik yang ingin melemahkan semangat umat Islam untuk berperang. Namun karena ada omongan-omongan dari orang-orang munafik yang melemahkan semangat umat Islam, maka dibentuklah musyawarah tentang masalah perang dan urusan keduniawian lainnya seperti halnya urusan politik, ekonomi dan sebagainya.

Mạ̣al al-shabid yang dapat dijadikan dasar tentang 'Permusawaratan' adalah redaksi wa shäwirhum fì al-amr (dan bermusyarahlah dengan mereka dalam urusan itu). Meskipun Rasulullah adalah pemimpin yang memiliki hak prerogatif untuk memutuskan sebuah perkara, akan tetapi melibatkan orang lain untuk bermusyarah demi kemaslahatan bersama adalah perintah Allah yang harus dijalankan.

Selain asas permusyawaratan, asas perwakilan juga terdapat di dalam al-Qur'an. Di dalam surah Ṭăhā [20] ayat 30-32, Allah berfirman:

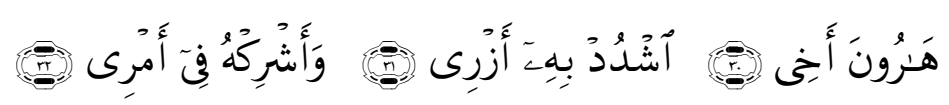

(yaitu) Harun, saudaraku, tegubkanlah dengan Dia kekuatanku, dan jadikankanlah Dia sekutu dalam urusanku. 
Konteks ayat di atas menceritakan tentang nabi Hārūn dan Mūsa. Sedangkan yang mendapatkan kitab Tawrat adalah nabi Müsa. Salah satu tugas seorang rasul adalah menyampaikan wahyu. Namun nabi Mūsa memiliki kelemahan dalam melafalkan ayat-ayat Allah. Konon, saat masih kecil ia memakan bara api sehingga lidahnya tidak dapat mengucapkan kata-kata dengan fasih. Atas kekurangan inilah nabi Mūsa memohon kepada Allah agar diangkat seorang wakil, dan nabi Hārūn adalah orang yang diajukan oleh nabi Mūsa kepada Allah. Permohonan itu dikabulkan dan jadilah nabi Hārūn sebagai 'juru bicara wahyu'.

Dalam konteks kenegaraan, seseorang tidak mungkin mengurus bangsa ini sendirian. Dengan segala kekurangan dan keterbatasannya, maka satu sama lain harus saling bahu-membahu untuk memajukan bangsa. Dari level yang tertinggi, Presiden misalnya, dalam menjalankan pemerintahannya dibantu oleh para menteri yang dinilai memiliki kapasitas untuk mengemban amanah tersebut. Dalam konteks kabupaten, Bupati mengangkat para camat untuk menjadi kepanjangan tangan atas berbagai kebijakan yang diemban oleh bupati.

Selain itu, suara rakyat juga dapat disalurkan melalui jalur pemilihan umum secara demokratis. Mereka memiliki hak penuh dalam pemilihan umum untuk menentukan presiden, gubernur, bupati atau walikota, DPR, DPD, DPRD dan sebagainya. Semua itu $100 \%$ di tangan rakyat. Oleh karenanya, dibutuhkan kedewasaan politik agar demokrasi yang mahal ini bisa menjadi kontestasi politik yang jujur dan bersih dari unsur-unsur money 
Spiritualis: vol. 6, no. 2, September, $2020 \mid 228$

politic yang dapat menciderai tujuan luhur tersebut. Semua elemen tidak dapat dikesampingkan. Jika ada pemerintah yang "nakal" dan bisa mempermainkan rakyatnya, maka dalam periode yang kedua, risikonya rakyat tidak akan memilihnya lagi. Dengan demikian akan tercipta simbiosis-mutualism antara rakyat dan pemerintah.

Selain ayat di atas, asas perwakilan juga terdapat di dalam surah Al-Nisā' [4] ayat 58 sebagai berikut:

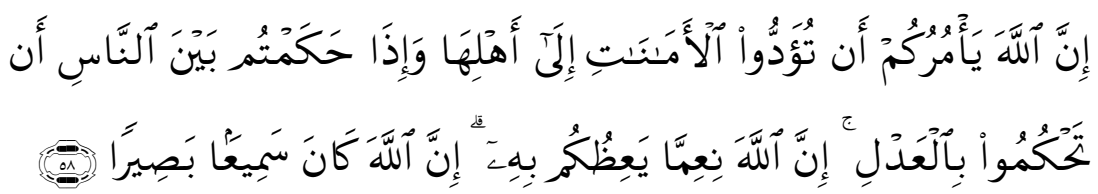

Sesunggubnya Allah menyurub kamu menyampaikan amanat kepada yang berbak menerimanya, dan (menyurub kamu) apabila menetapkan bukum di antara manusia supaya kamu menetapkan dengan adil. Sesunggubnya Allab memberi pengajaran yang sebaik-baiknya kepadamu. Sesunggubnya Allah adalab Maha Mendengar lagi Maha Melibat.

Konteks ayat ini membicarakan tentang kunci Ka'bah yang dipegang oleh Uthmān bin Talhạh. Saat peristiwa Fath Makkah, konon 'Ali bin Abi Ṭalib meminta kunci itu dari Ṭalḥah. Namun ada wahyu turun supaya kunci itu diberikan kepada ahlinya. Saat itu, orang yang berhak memegang kunci tersebut adalah keturunan dari Qusay bin Kilab. Pada masa Rasulullah, jabatan tersebut dipegang oleh Uthmān bin Țalhah sehingga Nabi memerintahkan agar kunci itu diserahkan kepadanya, meskipun pernah diminta oleh sanak saudaranya sendiri. Selain itu, ayat di atas juga memerintahkan berbuat adil kepada siapapun. Nabi tidak memihak Ali meskipun ia adalah sanak saudara sendiri, tetapi Nabi justru 
Spiritualis: vol. 6, no. 2, September, 2020 |229

memihak kepada Uthmān bin Ṭalhah yang notabene orang jauh, atas dasar keadilan, bukan kekerabatan.

Al-Qur'an bukanlah kitab yang berhenti kepada kasusperkasus. Jika hanya merujuk suatu kasus tertentu, maka hal ini disebut dengan al-íbrah bi khusus al-sabab là bi 'umūm al-lafă. Akan tetapi ada sudut pandang kedua, yaitu al-ibrah bi umum al-laf: là bi khusūs al-sabab. Dalam konteks kenegaraan, kita harus menggunakan kaidah yang kedua, yaitu dengan keumuman lafal. Ayat ini secara umum memerintahkan kepada umat Islam khususnya dan manusia pada umumnya untuk menyerahkan segala urusan kepada ahlinya. Dalam konteks pemilihan presiden, jika kita tidak dapat memegang beban berat itu, maka kita harus mewakilkan orang lain yang lebih kompeten dalam bidangnya. Begitu juga dengan pemilihan-pemilihan pemimpin yang lain, yaitu kita harus tahu diri kalau kita tidak mampu atau belum mampu sehingga wajib memilih pemimpin yang dininlai mumpuni dalam urusannya. Bukankah memilih pemimpin itu menurut pakar hukum tata negara pertama di dalam Islam, al-Māwardi, hukumnya wajib? ${ }^{14}$

5. Keadilan Sosial Bagi Seluruh Rakyat Indonesia

Presiden Joko Widodo dalam salah satunya sambutannya pernah menyatakan bahwa aspek paling berat dalam implementasi Pancasila adalah mewujudkan sila kelima, yaitu "Keadilan sosial bagi seluruh rakyat Indonesia". Ia menyampaikan bahwa

14 Abū Hasan 'Ali bin Muhammad bin Habīb al-Māwardi, al-Aḥkāam alSultāniyyah (Beirut: Dār al-Fikr, 1960), 1. 
ketimpangan sosial yang sangat mencolok terjadi di Indonesia timur. Oleh karena itu, dalam pemerintahannya harus memprioritaskan Indonesia timur. Presiden juga memberikan contoh riil, mengenai harga BBM yang mahalnya lebih dari 10 kali lipat harga normah. Begitu juga dengan harga semen dan berbagai kebutuhan lain. Penyebab dari mahalnya barang tersebut karena transportasi yang ada di sana kebanyakan melalui jalur udara. Untuk sementara waktu, negara harus hadir dan memberikan subsidi bagi barang-barang yang terlampau mahal agar rakyat Indonesia timur bisa menikmati harga yang sama dengan tempat yang lain. Untuk merealisasikan keadilan sosial jangka panjang, pemerintah harus membangun jalur darat yang memadahi agar wilayah-wilayah terpencil dapat dijangkau dan roda ekonomi cepat berkembang. Bukan sebaliknya, menunggu ekonominya tumbuh dan infrastrukstur baru dibangun. Itu hanyalah contoh kecil dari ketimpangan sila kelima yang belum terealisasi dengan baik.

Konsep keadilan sosial juga memiliki asas dari al-Qur'an. Allah berfirman di dalam surah Al-Mà'idah [5] ayat 8 sebagai berikut:

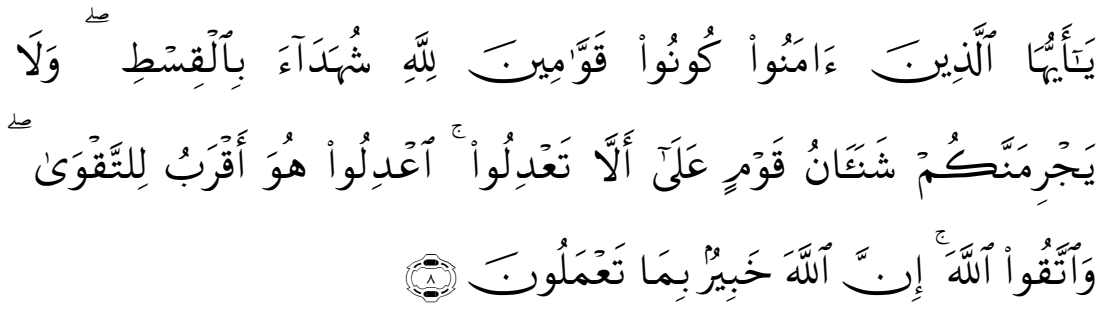

Hai orang-orang yang beriman hendaklah kamu Jadi orang-orang yang selalu menegakekan (kebenaran) karena Allah, menjadi saksi dengan adil. dan janganlah sekali-kali kebencianmu terhadap sesuatu kaum, mendorong kamu 
Spiritualis: vol. 6, no. 2, September, 2020 |231

untuk berlaku tidak adil. Berlaku adillah, karena adil itu lebih dekat kepada takwa. dan bertakwalah kepada Allah. Sesunggubnya Allab Maha Mengetahui apa yang kamu kerjakan.

Kata qawwamin di dalam ayat ini memiliki makna 'mendirikan keadilan dengan konsisten'. Tidak dibenarkan ada keadilan di dalam satu waktu namuan tidak di tegakkan di waktu yang lain. selain itu, umat Islam kelak akan menjadi saksi dihadapan Allah atas sikap adil itu. Jadi, secara langsung Allah memerintahkan orang-orang beriman agar menjadi saksi atas keadilan itu sendiri. Beban sebagai saksi ini tidak mudah, paling tidak ada dua kriteria yang harus dimiliki: pertama, seorang yang menjadi saksi harus membuktikan bahwa dia lebih baik daripada tersangka. Kedua, orang yang menjadi saksi adalah menjadi pengawas atas pelanggaran hukum yang dilakukan oleh seseorang. Itulah dua tugas yang dibebankan kepada orang-orang beriman.

Ayat ini dengan tegas memerintahkan umat Islam khususnya dan umat manusia pada umumnya agar selalu berlaku adil kepada siapapun. Dari segi geografis, tidak boleh ada dikotomi Indonesia timur atau barat, Jawa atau bukan Jawa. Karena itu semboyan pembangunan harus di dasarkan kepada Indonesia sentris, bukan Jawa sentris karena dengan itulah asas keadilan sosial bisa terwujud. Dari segi agama, tidak boleh ada dikotomi muslim dan non-muslim, sebab semua memiliki hak yang sama dan berjuang bersama-sama dalam mengibarkan merah-putih. Dalam redaksi walā yajrimannakum sana 'ànu qawmin menggambarkan larangan Allah, bahwa tidak boleh ada kebencian yang di atas-namakan kepada suatu kelompok, baik itu kelompok 
yang beda agama, beda geografis ataupun beda ras. Semua harus dipersamakan atas nama warga negara Indonesia. Jika hal tersebut dilanggar, maka secara langsung ataupun tidak langsung, ia sudah melanggar sila kelima, sekaligus melanggar perintah Allah.

Salah satu dalil tersirat di dalam al-Qur'an tentang keadilan sosial terdapat di dalam surah al-Tawbah [9] ayat 60 yang menjelaskan tentang hak-hak raktyat kecil.

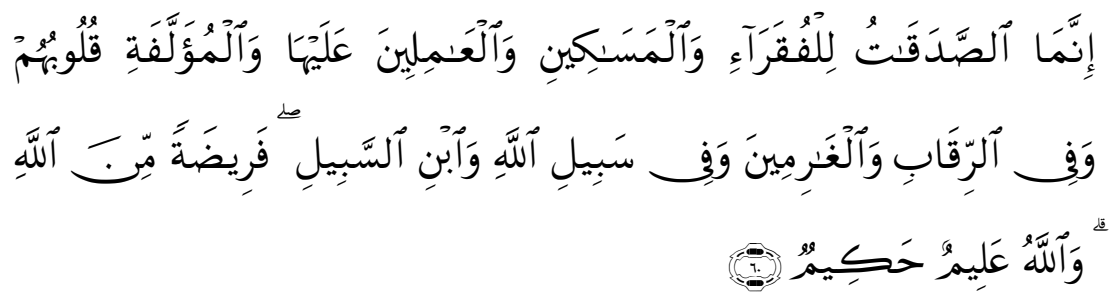

Sesunggubnya al-sadaqāt itu, hanyalah untuk orang-orang fakir, orang-orang miskin, pengurus-pengurus zakat, para mu'allaf yang lemah batinya, untuk (memerdekakan) budak, orang-orang yang berbutang, untuk jalan Allah dan untuk merek a yuang sedang dalam perjalanan, sebagai suatu ketetapan yang diwajibkan Allah, dan Allah Maha Mengetahui lagi Maha Bijaksana.

Konteks keadailan sosial yang ditekankan di dalam ayat ini adalah untuk mengentaskan kemiskinan atau minimal mengurangi ketimpangan sosial yang ada di masyarakat. Salah satu cara untuk mengentaskan kemiskinan di dalam Islam adalah dengan cara memberikan sedekah atau zakat kepada pihak-pihak yang berhak menerimanya. Di sinilah negara harus hadir dalam rangka untuk mengidentifikasi warganya yang berada di bawah garis kemiskinan, mengeluarkan kebijakan yang mampu mengentaskan kemiskinan dan membuat program-program yang pro rakyat kecil. 
Spiritualis: vol. 6, no. 2, September, 2020 |233

Secara spesifik al-Qur'an menyebutkan pihak-pihak yang berhak menerimanya ada delapan golongan. Pertama, orang fakir yaitu orang yang sengsara hidupnya. Ia tidak mempunyai harta dan pekerjaan untuk memenuhi kebutuhan pokok. Kedua, orang miskin, yaitu orang yang memiliki pekerjaan akan tetapi tidak dapat mencukupi kebutuhan pokok sehari-hari. Ketiga, 'amil zakat, yaitu orang yang diberi tugas untuk mengumpulkan dan membagikan zakat, berdasarkan surat tugas yang dikeluarkan oleh pemerintah. Keempat, muallaf, yaitu orang yang baru masuk Islam dan imannya masih lemah. Kelima, untuk memerdekakan budak. Keenam, gharim, yaitu orang yang banyak hutang untuk kepentingan perjuangan dan bukan maksiat serta tidak sanggup membayarnya. Ketujuh, sabīl lillah, yaitu untuk keperluan pertahanan Islam dan kaum muslimin, seperti mendirikan sekolah, rumah sakit dan kebutuhan sosial lainnya, dan; Kedelapan, orang yang sedang dalam perjalanan yang bukan maksiat dan mengalami kesengsaraan dalam perjalanannya.

Secara eksplisit itulah orang-orang yang dikategorikan layak mendapatkan perhatian dalam Islam. Dalam konteks kenegaraan, penulis kira tidak jauh berbeda. Artinya, mereka adalah golongan yang harus diperhatikan secara penuh oleh pemerintah agar ketimpangan sosial dari segi ekonomi ini tidak terlampau jauh dan berlarut-larut. Jadi, sistem yang ditawarkan Islam adalah dengan cara membayar zakat bagi orang-orang kaya untuk menopang ekonomi masyarakat bawah dan menerapkan pajak untuk barang atau jasa tertentu untuk kepentingan negara. Pada intinya, keadilan sosial dari segi ekonomi harus merata dan berjalan dengan baik 
Spiritualis: vol. 6, no. 2, September, 2020 |234

melalui kebijakan-kebijakan pemerintah yang pro rakyat kecil. Pada dasarnya, mengentaskan kemiskinan bukan hanya amanah undangundang, akan tetapi juga amanah Allah yang harus dilaksanakan oleh pemerintah untuk mencapai "Keadilan sosial bagi seluruh rakyat Indonesia”.

\section{Kesimpulan}

Pancasila memiliki asas yang kuat dengan al-Qur'an. Sila pertama "Ketuhanan Yang Maha Esa" memiliki asas di dalam surah al-Ikhlāṣ [112]:1 dan al-Baqarah [2]:163. Sila kedua "Kemanusiaan yang adil dan beradab" memiliki asas dari surah alShūra [42]:15 tentang perintah untuk berlaku adil dan surah alNaḥl [16]:90 tentang perintah untuk berlaku adil dan ị̣sān. Sila ketiga "Persatuan Indonesia" memiliki asas dari surah Āli 'Imrān [3]:103 yang memerintahkan agar berpegang teguh kepada tali Allah dan jangan bercerai-berai dan surah al-Hujurāt [49]:10 mengenai persaudaraan antar sesama dan ayat ke-13 mengenai perbedaan bangsa dan suku, supaya saling memahami satu sama lain. Sila keempat "Kerakyatan yang dipimpin oleh hikmat, kebijaksanaan dalam permusyawaratan perwakilan" memiliki asas dari surah al-Baqarah [2]:269 tentang hikemah; A Ali 'Imrān [3]:159 tentang permusyawaratan; Tăhā [20]:30-32 tentang perwakilan dan alNisā' [4]:58 tentang perwakilan sesuatu kepada ahlinya. Sila kelima "Keadilan sosial bagi seluruh rakyat Indonesia" memiliki asas dari surah al-Māidah [5]:8 tentang keadilan dan al-Tawbah [9]:60 tentang keadilan sosial terutama yang memihak kepada rakyat kecil. 
Spiritualis: vol. 6, no. 2, September, 2020 |235

\section{DAFTAR PUSTAKA}

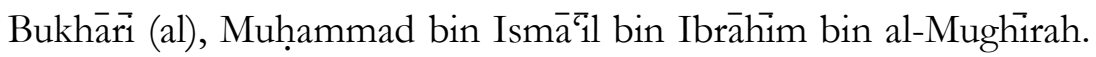
al-Jāmi‘ al-Saḥiḥ. Kairo: Dār al-Shu'ab, 1987.

Fayrūzi (al) Abadī,Abū Tăhir bin Ya'qūb. Tanwìr al-Miqbās min Tafsìr Ibni 'Abbās. Kairo: Shirkah al-Quds, 2007.

Ibnu Kathīr, Abū al-Fidā' Ismā̄ill bin 'Umar. Tafsìr al-Qur'an alAžim. Kairo: Dār Taybah, 1999.

Māwardì (al), Abū Hasan 'Ali bin Muhammad bin Habīb. al-Nukat wa al-'Uyūn. Beirut: Dār al-Kutub al-'Ilmiyyah, 2012.

al-Ạ̣kām al-Sultāiniyyah. Beirut: Dār al-Fikr, 1960.

Muslim, Abū al-Ḥusayn Muslim bin al-Hajjaj bin Muslim alQushayri. Saḥiḥ Muslim. Beirut: Dār al-Āfàq al-Jadidah, t. Th.

Qurțubi (al), Abū 'Abd Allāh Muḥammad bin Aḥmad bin Abū Bakr bin Farh al-Anșāri Shams al-Dīn. al-Jāmi' li Aḅkām alQur'àn. Riyạ̣̄: Dār 'Älim al-Kutub, 2003.

Rohman, Abdur. "Poligami" dalam jurnal Agenda, IAIN Batusangkar, vol. 2 nomor 1 Juli-Desember, 2019.

----------, Tafseer Verses of Diversity, dalam Proceeding "Medorasi Islam Aswaja untuk Perdamaian Dunia" IAIFA Pare Kediri, vol. 1, 2019.

Samarqandi (al), Abū al-Layth Naṣr bin Muhammad bin Ibrāhïm. Bạ̣r al-'Ulüm (al-Maktabah al-Shāmilah). 
Spiritualis: vol. 6, no. 2, September, $2020 \mid 236$

Zamakhsharī (al), Abū al-Qāsim Maḥmūd bin 'Umar. al-Kashshāf 'an Haqa'iq al-Ghawamid al-Tañīl wa 'Uyūn al-Aqāwil fí Wujūh al-Ta'wìl. Beirut: Dār al-Kutub al-'Arabì, 1407.

Zuhayli (al), Wahbah bin Muștafä. al-Tafsìr al-Munir fì al-'Aqìdah wa al-Sharīah wa al-Manhaj. Beirut: Dār al-Fikr al-Ma'ạșir, 2016. 